\title{
Spawning, Development, and the Duration of Larval Life in a Deep-Sea Cold-Seep Mussel
}

Shawn M. Arellano

Western Washington University, shawn.arellano@wwu.edu

Craig M. Young

Follow this and additional works at: https://cedar.wwu.edu/shannonpoint_facpubs

Part of the Marine Biology Commons

\section{Recommended Citation}

Shawn M. Arellano and Craig M. Young, "Spawning, Development, and the Duration of Larval Life in a Deep-Sea Cold-Seep Mussel," The Biological Bulletin 216, no. 2 (April 2009): 149-162.

This Article is brought to you for free and open access by the Shannon Point Marine Center at Western CEDAR. It has been accepted for inclusion in Shannon Point Marine Center Faculty Publications by an authorized administrator of Western CEDAR. For more information, please contact westerncedar@wwu.edu. 


\title{
Spawning, Development, and the Duration of Larval Life in a Deep-Sea Cold-Seep Mussel
}

\author{
SHAWN M. ARELLANO ${ }^{1,2, *}$ AND CRAIG M. YOUNG ${ }^{1}$ \\ ${ }^{1}$ Oregon Institute of Marine Biology, University of Oregon, P.O. Box 5389, Charleston, Oregon 97420 \\ ${ }^{2}$ Current address: Department of Biology, The Hong Kong University of Science and Technology, \\ Clear Water Bay, Hong Kong SAR.
}

\begin{abstract}
We describe culturing techniques and development for the cold-seep mussel "Bathymodiolus" childressi, the only deep-sea bivalve for which development has been detailed. Spawning was induced in mature mussels by injection of $2 \mathrm{mmol}^{-1}$ serotonin into the anterior adductor muscle. The mean egg diameter is $69.15 \pm 2.36 \mu \mathrm{m}$ ( \pm S.D.; $n=50)$ and eggs are negatively buoyant. Cleavages are spiral and at $7-8{ }^{\circ} \mathrm{C}$ occur at a rate of one per 3-9 $\mathrm{h}$ through hatching, with free-swimming blastulae hatching by $40 \mathrm{~h}$ and shells beginning to develop by day 12 . When temperature was raised to $12-14{ }^{\circ} \mathrm{C}$ after hatching, larvae developed to D-shell veligers by day 8 without being fed. Egg size and larval shell morphology indicate that " $B$." childressi has a planktotrophic larva, but we did not observe feeding in culture. Wide distribution of this species throughout the Gulf of Mexico and amphi-Atlantic distributions of closely related congeners suggest that larvae may spend extended periods in the plankton. Duration of larval life was estimated for "B." childressi by comparing calculated settlement times to known spawning seasons. These estimates suggest variability in the larval duration, with individuals spending more than a year in the plankton.
\end{abstract}

\section{Introduction}

Earlier predictions that development in the deep sea should be limited to brooding and direct development (e.g., Thorson, 1950) have now been negated (Pearse, 1994; Young, 1994), and it is well-accepted that virtually all known modes of development are found in the deep sea (reviewed by Young, 2003). Ever since abundant life was

Received 23 Feb 2008; accepted 3 November 2008.

* To whom correspondence should be addressed. E-mail: arellano@ ust.hk discovered at hydrothermal vents (Lonsdale, 1977; Corliss and Ballard, 1977) and later at cold methane seeps (Paull et al., 1984; Hecker, 1985) it has been recognized that larval dispersal is a central issue in understanding the connectedness and colonization of these patchy and often ephemeral habitats (Corliss and Ballard, 1977; Corliss et al., 1979; Lutz et al., 1980, 1984). Moreover, it was soon recognized that our traditional understanding of the relationships among developmental mode, dispersal potential, and geographic range may not always hold true in these chemosynthetic systems (Lutz et al., 1980, 1984) or even in the deep sea in general (Young et al., 1999). For example, planktotrophic (feeding) larvae are generally presumed to disperse for longer times and greater distances than lecithotrophic larvae or brooded embryos (Thorson, 1950; Wray and Raff, 1991), but developmental and metabolic rates decrease with temperature (Clarke, 1983) and can result in an extended dispersal potential for lecithotrophic larvae in the cold deep sea (Lutz et al., 1984; Turner et al., 1985; Gustafson and Lutz, 1994; Young et al. 1997; Le Pennec and Beninger, 2000; reviewed by Young, 2003; O'Connor et al., 2007). Laboratory studies describing developmental modes, developmental rates, larval duration, and physiological tolerances of larvae as well as current measurements in the field are required to relate developmental mode to dispersal potential and geographic distribution (Lutz et al., 1984; Turner et al., 1985).

Culturing larvae of deep-sea species was once thought impossible (e.g., Turner et al., 1985) and is admittedly difficult. Nevertheless, a number of deep-sea invertebrates have been cultured at least through the early larval stages. For example, numerous bathyal echinoderms have been cultured to the four-arm pluteus stage (Mortensen, 1921; Young and Cameron, 1989; Young et al., 1989), and two 
species have been reared to more advanced stages (Prouho, 1888; Young and George, 2000). It is much more difficult to culture species from abyssal depths, where embryos often require high pressures to develop (Young and Tyler, 1993; Young et al., 1996a). Nevertheless, a few hydrothermalvent and cold-seep organisms have been cultured through the early embryonic stages, with the abyssal vent organisms requiring the use of pressurization techniques (Young et al., 1996b; Eckelbarger et al., 2001; Pradillon et al., 2001, 2005; Marsh et al., 2001).

Mytilid mussels, which are among the most prominent members of many reducing communities, inhabit a wide depth range of cold-seep communities along the upper continental slope in the northern Gulf of Mexico. Five species of mytilid mussels of the subfamily Bathymodiolinae have been described from seeps in this region (Gustafson et al., 1998). Among them, "Bathymodiolus" childressi Gustafson et al., 1998, a mixotrophic mussel harboring methane-oxidizing endosymbionts in the gills, resides at cold seeps over a depth range from $\approx 540 \mathrm{~m}$ to $2200 \mathrm{~m}$ (Gustafson et al., 1998). The unique morphology of "B." childressi (Gustafson et al., 1998) and a recent analysis of molecular phylogeny (Jones et al., 2006) evoke uncertainty about the placement of this species in the genus Bathymodiolus, leading to the use of quotation marks around the genus name of "Bathymodiolus" childressi (Gustafson et al, 1998; Jones et al., 2006). Within the Gulf of Mexico, there is no evidence for genetic differentiation between " $B$." childressi populations from the shallowest and deepest seep sites, nor is there a relationship between genetic structure and geographic distance across its range, suggesting widespread larval dispersal (Carney et al., 2006). Small egg size, postulated high fecundity, and the shell apices of four vent bathymodiolin mussels (reviewed in Tyler and Young, 1999) and three seep bathymodiolin mussels including "B." childressi (Gustafson and Lutz, 1994, Gustafson et al., 1998) all suggest that these species develop planktotrophically and therefore may have high dispersal potential.

Neither the developmental mode nor larval duration of "B." childressi has been determined. Moreover, no descriptions of either early embryology or complete larval development have been published for any deep-sea mollusc (reviewed by Young, 2003; but see Van Gaest, 2006). This study provides the first description of larval culturing techniques and larval development through the early veliger stage for any hydrothermal-vent or cold-seep bivalve and includes a description of the larval shell that can assist in identifying larvae collected from the plankton. We also provide an indirect estimate of larval life span based on a comparison of known spawning times with settlement times estimated from field data on juvenile growth and recruitment.

\section{Materials and Methods}

\section{Collection sites}

"Bathymodiolus" childressi adults were collected from two cold-seep sites on the upper continental slope of Louisiana. Mussels were sampled primarily from Brine Pool NR1 $\left(27^{\circ} 43^{\prime} 24^{\prime \prime} \mathrm{N}, 91^{\circ} 16^{\prime} 30^{\prime \prime} \mathrm{W}\right)$, a brine-dominated seep located about $285 \mathrm{~km}$ southwest of the Mississippi Delta at a depth of $\approx 650 \mathrm{~m}$ (MacDonald et al., 1990). When compared to mussels at sites dominated by petroleum seepage (MacDonald, 1998), mussels at the Brine Pool tend to have faster growth and better physiological condition (Nix et al., 1995; Bergquist et al., 2004). Occasionally, mussels were sampled from Bush Hill $\left(27^{\circ} 47^{\prime} \mathrm{N}, 91^{\circ} 30^{\prime} 24^{\prime \prime} \mathrm{W}\right)$, an oildominated seep at $\approx 540 \mathrm{~m}$ depth that is characterized by large aggregations of vestimentiferan tubeworms associated with clumps of “B." childressi mussels (McDonald, 1998). Mussels at this site grow relatively slower and are in poorer physiological condition than those at Brine Pool (Nix et al., 1995; Bergquist et al., 2004).

\section{Collection and maintenance}

The Johnson-Sea-Link I and II submersibles (Harbor Branch Oceanographic Institution) were used to collect samples. Collections were made with the submersible's hydraulic clamshell scoop and placed in a thermally stable acrylic box for transport to the surface. Additionally, mussels were placed in plastic mesh cages at the Brine Pool and recovered later using acoustic releases (see Tyler et al., 2007). Once on deck, the mussels were immediately transferred to clean, cold seawater and maintained in a cold room $\left(7-8{ }^{\circ} \mathrm{C}\right)$ until they were transported back to the Oregon Institute of Marine Biology (OIMB). When shipboard maintenance time was lengthy (up to 2 weeks), aquaria containing mussels were bubbled with methane gas periodically and aerated constantly, and seawater was changed regularly.

Aquaria for long-term maintenance at OIMB consisted of a row of six recirculating tanks (150 l each) connected to a titanium-coil seawater chiller set at $7-8{ }^{\circ} \mathrm{C}$. Plastic baskets containing the mussels were transferred daily to a chilled recirculating feeding tank (200 1) where mussels were "fed" by bubbling methane and air into the tank for at least 30 min. Methane levels reach greater than $200 \mu \mathrm{mol} \mathrm{l}^{-1}$ at the Brine Pool cold seep (Smith et al., 2000), but only up to 60 $\mu \mathrm{mol} 1^{-1}$ at Bush Hill (Nix et al., 1995). Because we were unable to measure the methane concentrations in the seawater to determine when the system was saturated with methane, we left mussels in the feeding tank for at least $3 \mathrm{~h}$ with only air bubbling into them, allowing time to oxidize any remaining methane. Both tank systems were filled with raw seawater from the OIMB running seawater system, which pumps from the inlet of Coos Bay, Oregon, only on incoming tides (salinity 32). Seawater was changed approx- 
imately monthly in the feeding tank and once every few months in the maintenance tanks.

\section{Spawning and culturing}

Histological evidence indicates that "B." childressi at the Brine Pool and Bush Hill spawn periodically each year over an extended period that lasts from October to February (Tyler et al., 2007). Mussels collected prior to the known spawning season were maintained for up to several months and used for developmental studies in the late fall and winter.

Spawning and culturing procedures were developed from recommendations reviewed by Strathmann (1987). Spawning was induced in mature mussels (sizes ranging from $\approx 50$ $\mathrm{mm}$ to $\approx 120 \mathrm{~mm}$ ) by a $0.4-0.5-\mathrm{ml}$ injection of $2 \mathrm{mmol}$ $1^{-1}$ serotonin into the anterior adductor mussel. Prior to injection, mussels were scrubbed and rinsed in fresh water. After injection, about 12 mussels were placed in a single 4-1 container of $0.22-\mu \mathrm{m}$ filtered seawater and kept in a $7-8{ }^{\circ} \mathrm{C}$ cold room until they spawned. After mussels spawned, fertilized eggs were cleaned and placed in clean $0.22-\mu \mathrm{m}$ filtered seawater. Embryos were maintained in a $7-8{ }^{\circ} \mathrm{C}$ cold room. One set of cultures in November 2003 (Table 1) was divided after hatching between a $12-14{ }^{\circ} \mathrm{C}$ seawater table and the $7-8{ }^{\circ} \mathrm{C}$ incubator. For general maintenance, dense cultures (up to 50 embryos per ml) were kept in 2-1 glass jars and were not stirred. Larvae were fed Isochrysis galbana (approximately 40,000 cells per $\mathrm{ml}$ ) after hatching, and water was changed daily.

\section{Microscopy}

Light micrographs were taken of each developmental stage on an Olympus BX50 compound microscope with a
$40 \times$ Nomarski DIC objective, using an Optronics Microfire digital camera. Developing shells were visualized using cross-polarizing filters.

Representative stages were fixed for scanning electron microscopy in $2.5 \%$ glutaraldehyde, washed with Millonig's $0.2 \mathrm{~mol} \mathrm{l}^{-1}$ sodium phosphate buffer wash, and post-fixed in $1 \%$ osmium tetroxide buffered in $0.4 \mathrm{~mol}^{-1}$ Millonig's buffer and $0.75 \mathrm{~mol}^{-1} \mathrm{NaCl}$ (1:1:2). Scanning electron micrographs were taken of eggs, embryos, and larvae on a JEOL 6400F field emission scanning electron microscope.

\section{Embryological timing}

Because spawning attempts were most successful when multiple mussels were placed in a single container over an extended period of time, our cultures were never synchronous. We drew regular samples of at least 100 embryos and staged them all under $40 \times$ magnification to construct an approximate timetable for development at $7-8{ }^{\circ} \mathrm{C}$. However, because we could not pinpoint a fertilization time (as can be done with synchronous cultures), our timetable was measured from the time that sperm were removed from the cultures.

\section{Estimation of planktonic larval duration}

Scoops of "B." childressi were taken from the "inner zone" (Smith et al., 2000; Arellano, 2008) of the Brine Pool cold seep in March 2002, October 2002, February 2003, September 2003, November 2003, and July 2004. Upon recovery of the mussels, we counted and measured new recruits (individuals $\leq 10 \mathrm{~mm}$ ) and plotted the size-frequency distributions of individuals in 1-mm bins. From the measured lengths, we back-calculated the approximate date

Table 1

Summary of data on collection and maintenance of large "Bathymodiolus" childressi mussels from the Brine Pool and Bush Hill cold seeps, spawning conditions, and maximum developmental stage attained before cultures ceased developing

\begin{tabular}{|c|c|c|c|c|}
\hline \multirow[b]{2}{*}{ Collection date } & \multicolumn{2}{|c|}{ Adult mussel maintenance } & \multicolumn{2}{|c|}{ Spawning conditions } \\
\hline & Months maintained at OIMB & Month induced & Induced separately? ${ }^{1}$ & Max. dev. stage \\
\hline June \& October 2002 & $2-5$ & December 2002 & Yes & 16-cell \\
\hline June \& October 2002 & $3-6$ & January 2003 & No & Shells forming \\
\hline February 2003 & 0.5 & March 2003 & No & Hatched \\
\hline November 2003 & 0.5 & December 2003 & No & Hatched \\
\hline November 2003 & 0.5 & December 2003 & Yes & No fertilization \\
\hline November 2003 & 2 & January 2004 & Both & D-shell ${ }^{2}$ \\
\hline November $2003^{3}$ & 2.5 & February 2004 & Yes & Hatched \\
\hline July 2004 & 5 & January 2005 & Yes & Few hatched \\
\hline July 2004 & 6 & February 2005 & Yes & No development \\
\hline August 2006 & $2-3$ & October-November 2006 & No & Hatched \\
\hline
\end{tabular}

\footnotetext{
${ }^{1}$ Mussels were either maintained together or kept in separate containers during induction of spawning.

${ }^{2} \mathrm{D}$ shells developed in a culture that had been raised from an incubation temperature of $7-8{ }^{\circ} \mathrm{C}$ to $12{ }^{\circ} \mathrm{C}$ about $48 \mathrm{~h}$ after hatching.

${ }^{3}$ Some of the mussels induced were maintained at C.R. Fisher's lab at The Pennsylvania State University for up to one year.
} 
of settlement, using a settlement size of $0.5 \mathrm{~mm}$ long (the approximate size of the prodissoconch in newly settled juveniles) and the mean growth rate determined by a markrecapture experiment. Six individuals ranging in length from 9 to $18.5 \mathrm{~mm}$ were attached, using cyanoacrylate adhesive ("super glue"), in a known order to sheets of 1-mm plastic mesh and placed in cages $\left(13 \times 13 \times 8 \mathrm{~cm}^{3}\right)$ near the Brine Pool (Arellano, 2008). Upon recovery of the mussels 8 months later, we measured the lengths of the individuals again and calculated a mean growth rate of $1.44 \pm 0.30$ (S.D.) $\mathrm{mm} 30 \mathrm{~d}^{-1}$ (Arellano, 2008). This calculated growth rate also agrees with the growth rate for this size class calculated from Smith et al. (2000). We plotted the estimated percentage of individuals settling each month over the entire sampling period.

\section{Shell description}

Veloconcha were collected with larval tube traps placed at the Brine Pool cold seep. Tube traps were PVC pipes 5 $\mathrm{cm}$ wide and $30 \mathrm{~cm}$ tall (aspect ratio $=6$ ) that were mounted on iron discs that weighed $\approx 2 \mathrm{~kg}$. The tubes had their tops open to capture larvae by horizontal advection across the openings (Yund et al., 1991). Studies suggest that cylindrical traps with aspect ratios above 4 are least susceptible to resuspension (Yund et al., 1991). In our samples, very few bivalves captured had begun to form a dissoconch. Larval tube traps were filled with $10 \%$ formalin buffered in seawater to prevent escape of larvae (Yund et al., 1991). Post-larvae were collected from settlement racks (Arellano, 2008) and from nylon mesh ("S.O.S.Tuffy") scouring pads placed on the "B." childressi mussel bed at the Brine Pool cold seep. Upon recovery, veloconcha and juveniles were transferred to $70 \%$ ethanol.

Shells were cleaned in 5\% sodium hypochlorite solution, rinsed with distilled water, air-dried, and mounted on adhesive carbon discs for scanning elecron microscopy (Rees, 1950; Fuller and Lutz, 1989). Procedures to accurately document the shapes and dimensions of the larval bivalve shells were modified from those of Fuller et al. (1989). The following measurements were taken for 10 larval and postlarval shells: height and length of prodissoconch II or dissoconch, shell length and straight hinge length of the prodissoconch I (if possible), provinculum length, and number of teeth. For larval shells, length is the greatest dimension approximately parallel to the provinculum and height is the greatest dimension perpendicular to the hinge line. For post-larval shells, dimensions follow the convention for adults, with length measured as the greatest anteroposterior dimension and height as the greatest dorsoventral dimension (Gosling, 1992).

\section{Results}

\section{Spawning and culturing}

Vigorous handling, rapid temperature changes, stretching of the adductor muscles, and electrical shock have proved successful in inducing spawning in mussels and other bivalves (Strathmann, 1987), but none of these techniques induced spawning in "Bathymodiolus" childressi. Serotonin injection induced spawning in mature mussels usually within about 8-12 h. Spawning was most successful when several mussels that had been injected with serotonin were placed in a single container. Attempts to spawn mussels in individual containers to keep sperm and eggs separate were mostly unsuccessful, but occasionally produced cultures that developed to hatched blastula larvae (Table 1). Spawning could be induced regularly in mussels that had been maintained in the laboratory for up to several months (Table 1). Twice, mussels that were maintained in C.R. Fisher's laboratory at The Pennsylvania State University for up to one year were induced to spawn with serotonin injection. However, normal development proceeded to the D-shell veliger stage only once: when mussels were collected during their spawning season and maintenance time at OIMB was less than 2 months (Table 1).

Natural spawning occurred in the laboratory on two occasions. In both cases, mussels were collected late in the summer. Mussels that were collected in July 2004 and August 2006 spawned in late August to September 2004 and late August 2006, respectively. In both years these cultures developed to hatched blastula larvae but never began forming shells.

Mussels released gametes bound in mucus, but eggs easily dissociated from the mucus. No attempts were made to estimate fecundity, as induction with serotonin can be unreliable and often induced spawning of immature oocytes.

\section{Development}

The mean egg diameter was $69.15 \pm 2.36 \mu \mathrm{m}( \pm$ S.D.; $n=50$ ). Eggs are negatively buoyant, and eggs and embryos are dense and optically opaque. Fertilization was evident by appearance of a thin fertilization envelope (Fig. 1b). In no case was fertilization $100 \%$ successful; generally it was less than $50 \%$. Polar bodies appeared within about $2.5 \mathrm{~h}$ of fertilization (Figs. 1c, 2a; Table 2). Polar lobes developed prior to first cleavage (Fig. 1c), which resulted in two unequal blastomeres ( $\mathrm{AB}$ and $\mathrm{CD}$ ) (Figs. 1e, 2b). After 7-15 $\mathrm{h}$, the second cleavage produced three equal bastomeres (A, B, C) and a larger D blastomere (Figs. 1f, 2c; Table 2). Successive cleavages followed the typical molluscan spiral cleavage pattern at an average developmental rate (at $7-8{ }^{\circ} \mathrm{C}$ ) of one division per $3-9 \mathrm{~h}$ through hatching, with 

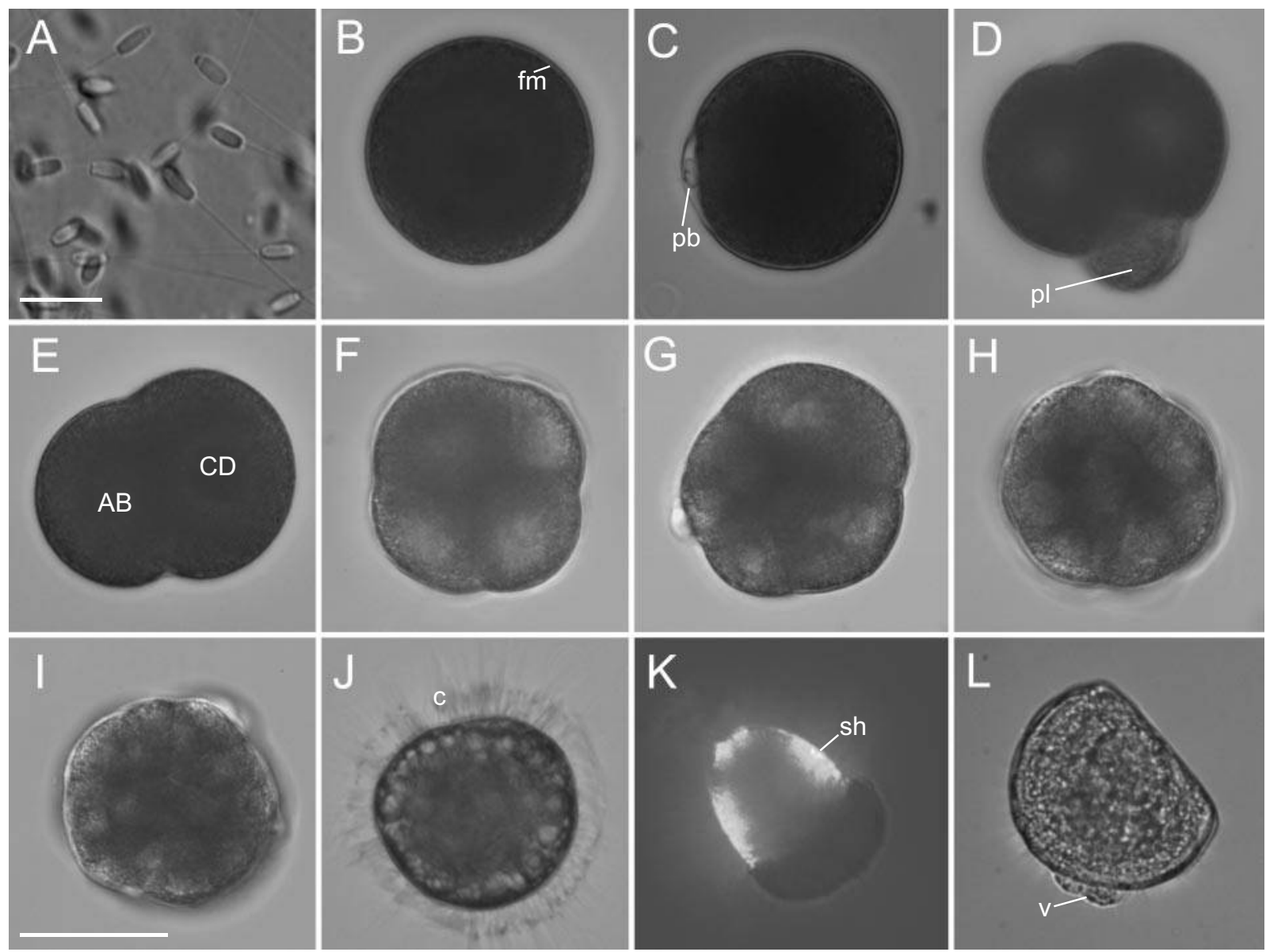

Figure 1. Light micrographs of "Bathymodiolus" childressi gametes and larvae. (A) Sperm, with clearly visible acrosomes, scale bar $=30 \mu \mathrm{m}$; (B) fertilized egg; (C) polar body extrusion; (D) third polar lobe; (E) 2-cell stage with $\mathrm{AB}$ and $\mathrm{CD}$ cells indicated; (F)-(I) 4-32-cell stages; (J) hatched blastula with long uniform cilia; (K) shell formation with shells illuminated by cross-polarized light; and (L) D-shell veliger larva. (B)-(L) Scale bar $=50 \mu \mathrm{m}$. fm, fertilization membrane; pb, polar body; pl, polar lobe; c, cilia; sh, shell; $\mathrm{v}$, velum.

free-swimming blastula larvae hatching from their fertilization envelopes by $40 \mathrm{~h}$ (Table 2).

At $7-8{ }^{\circ} \mathrm{C}$, shells began forming on day 6 . In cultures that were increased in temperature to $12-14{ }^{\circ} \mathrm{C}$ after hatching, more individuals developed shells than in cultures that remained at $7-8{ }^{\circ} \mathrm{C}$. On day $6,11 \%$ had shells in $7-8{ }^{\circ} \mathrm{C}$ cultures $(n=101)$ and $28 \%$ had shells in $12-14{ }^{\circ} \mathrm{C}$ cultures $(n=103)$. In some cases, development was delayed, with larval shell formation beginning as late as day 12. Larvae developed to $\mathrm{D}$-shell veligers by day 8 in cultures that were increased to $12-14{ }^{\circ} \mathrm{C}$ after hatching, and these larvae were never fed. At day 10, these D-shell veligers ranged from 86.70 to $103.56 \mu \mathrm{m}$ long $( \pm$ S.D. $=96.24 \pm 8.31 ; n=4)$.

There was no evidence that larvae fed on Isochrysis galbana in the laboratory. Algae were not observed in the gut either with normal DIC optics or with epifluorescence. Cultures were maintained for up to 2 weeks but never metamorphosed in the lab.

Although we could not rear larvae to metamorphosis, we estimated the planktonic larval duration by examining the size distribution of new recruits. Generally, we saw only one clear size peak of individuals $\leq 10 \mathrm{~mm}$ per sampling period (Fig. 3). Putting all the samples together, we estimated five distinct settlement peaks over the 34-month period (Fig. 4; Table 3). The largest calculated settlement peak occurred in November 2001 (Fig. 4), resulting in the recruits we collected in March 2002 (Fig. 3). Although this larger peak is due in part to higher sampling effort, we did note a higher percentage of new recruits in the March 2002 collection than in any other sample; nearly $50 \%$ of all the mussels collected were $\leq 10 \mathrm{~mm}$ in length. This size class made up less than $30 \%$ of the total sample in all other sampling periods (Arellano, 2008). By comparing the dates of the calculated settlement peaks to the spawning periods immediately preceding them, we estimated a planktonic larval duration of up to 13 months (Table 3).

Figure 5 shows larval and post-larval shells of "B." childressi collected in larval tube traps and on settlement 


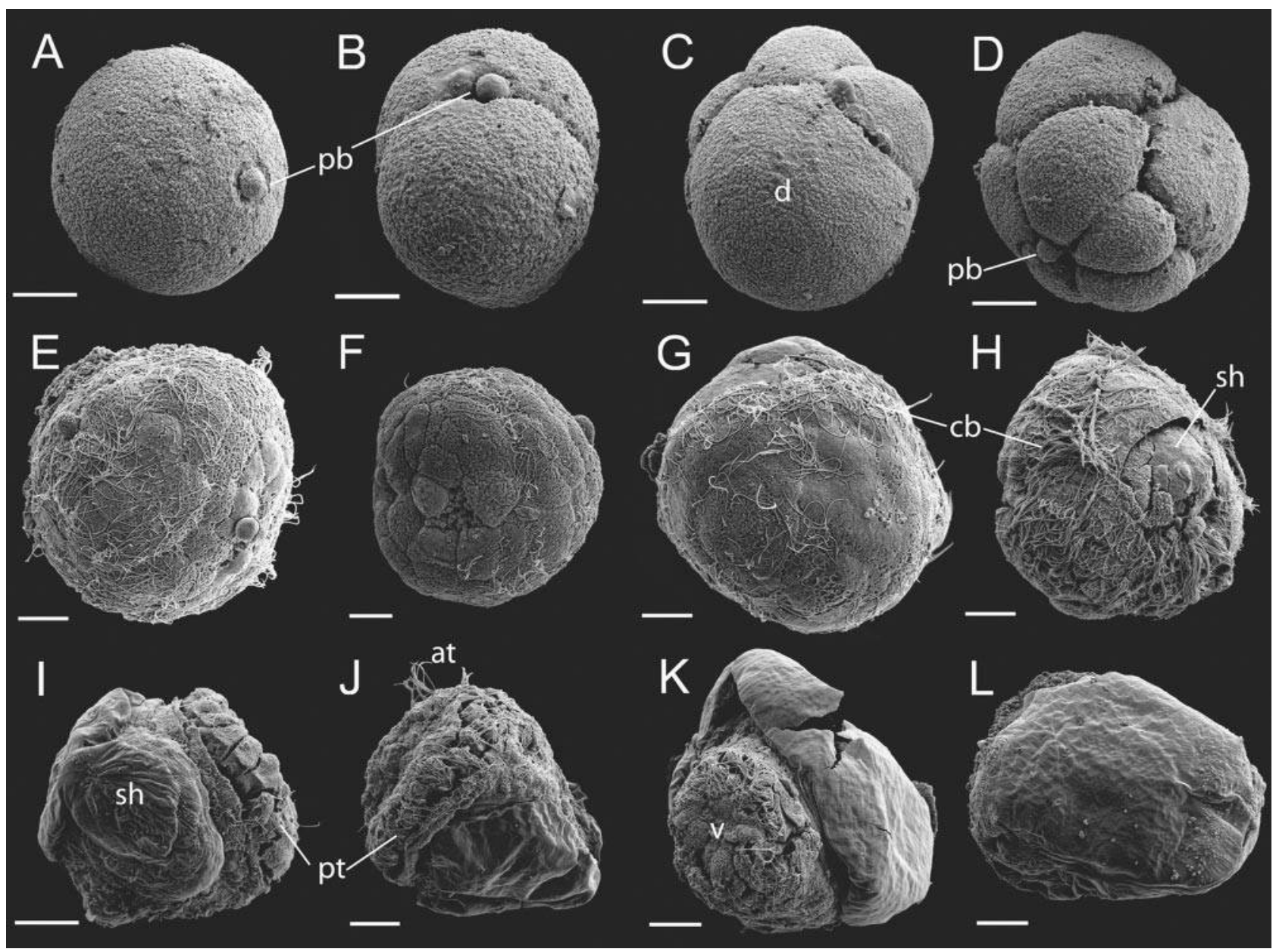

Figure 2. Scanning electron micrographs of embryos and larvae of "Bathymodiolus" childressi. (A)-(D) Polar body through 8-cell stages; (E)-(H) ciliary band formation; and (I)-(L) early veligers. Scale bars $=10 \mu \mathrm{m}$. pb, polar body; d, large D cell; cb, ciliary band; sh, shell; pt, primary trochoblasts; at, apical tuft; v, velum.

surfaces. Prodissoconchs I and II were reddish (as previously noted by Gustafson et al., 1998), in sharp contrast to the yellowish dissoconchs (Fig. 6). Lengths of larval shells

Table 2

Approximate developmental timetable for "Bathymodiolus" childressi

\begin{tabular}{|c|c|}
\hline Age (hours) ${ }^{1}$ & Developmental stages present \\
\hline 2.5 & Polar body extrusion-2-cell \\
\hline 7 & Polar body extrusion-4-cell \\
\hline 15 & $4-8$-cell \\
\hline 21 & 8-16-cell \\
\hline 30 & 32-cell-morula \\
\hline 40 & 32-cell-hatched \\
\hline$\approx 170$ & Shelled \\
\hline$\approx 50$ & Shelled $^{2}$ \\
\hline$\approx 185$ & D shell veligers ${ }^{2}$ \\
\hline
\end{tabular}

${ }^{1}$ Ages are the earliest noted development times at $7-8{ }^{\circ} \mathrm{C}$.

${ }^{2}$ Culture temperature was raised to $12{ }^{\circ} \mathrm{C}$ after hatching.
(PII) collected in the tube traps ranged from 432.71 to $453.60 \mu \mathrm{m}( \pm$ S.D. $=442.56 \pm 8.84 \mu \mathrm{m} ; n=5)$. For these shells, the length of prodissoconch I was $113.35 \pm 2.02 \mu \mathrm{m}$ and the provinculum was $210.15 \pm 10.94 \mu \mathrm{m}$ long, with 31 teeth (Table 4, Fig. 5b). Teeth along the hinge line were numerous and fine and increased in size along the anterior and posterior extensions of the provinculum (Fig. 5b). Larval shells exhibited the "egg shape" (Figs. 4, 5) that is characteristic of mytilids (Chanley, 1970; Le Pennec, 1980).

\section{Discussion}

A major hurdle to the study of hydrothermal-vent and cold-seep organisms is the extreme difficulty of culturing their larvae. To date, only a handful of hydrothermal-vent and cold-seep organisms have been cultured. The vestimentiferan tubeworm Riftia pachyptila (Marsh et al., 2001) and the alvinellid polychaete Alvinella pompejana (Pradillon et al., 2001, 2005), both from the East Pacific Rise, have been 


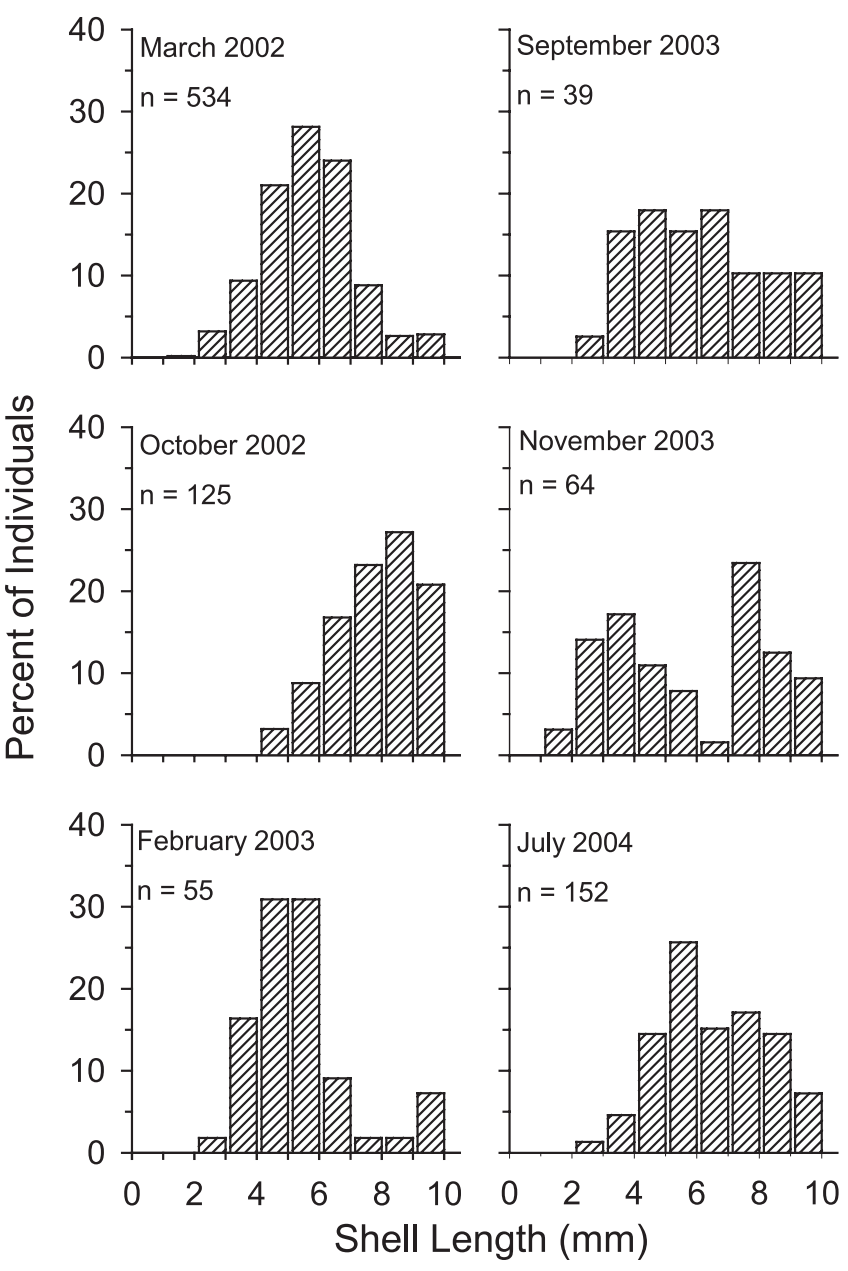

Figure 3. Size-percent frequency for new recruits ( $\leq 10$-mm length) of "Bathymodiolus" childressi at the Brine Pool cold seep in March and October 2002; February, September, and November 2003; and July 2004.

cultured using pressurization techniques. More recently, Miyake et al. (2006) cultured the vestimentiferan tubeworm Lamellibrachia satsuma that inhabits shallower hydrothermal vents in Kagoshima Bay, Nankai Trough, and along the Izu-Pgasawara Ridge at atmospheric pressure. From cold seeps in the Gulf of Mexico, two vestimentiferan tubeworms, Lamellibrachia luymesi and Seepiophila jonesi, have been cultured to trochophore larvae (Young et al., 1996b); the polychaete "iceworm" Hesiocaeca methanicola that resides in methane hydrates at seep sites has been cultured to early ciliated larvae (Eckelbarger et al., 2001); and most recently, encapsulated embryos of the cold-seep neritid gastropod Bathynerita naticoidea have been reared in the laboratory to free-swimming, feeding veligers (Van Gaest, 2006). Bathymodiolin mussels, which are dominant members of both hydrothermal-vent and cold-seep communities, have not been cultured until now, nor has their larval development been described previously.
Spawning

Like their shallow-water mytilid ancestors (Strathmann, 1987), there is evidence that the hydrothermal vent mussels Bathymodiolus azoricus (Comtet and Desbruyères, 1998; Comtet et al., 1999; Colaço et al., 2006) and Bathymodiolus puteoserpentis (Le Pennec and Beninger, 1997) have seasonal gametogenic cycles. Likewise, gametogenesis in " $\mathrm{Ba}$ thymodiolus" childressi is strongly periodic and synchronous among at least three seep sites in the Gulf of Mexico, with the initiation of gametogenesis from December to March, followed by a period of gamete proliferation and spawning from October to February of the following year (Tyler et al., 2007). In the laboratory, "B." childressi spawned most readily and cultures developed the furthest when they were collected in November 2003, which is the middle of their spawning season (Tyler et al., 2007), and maintained in the laboratory for only a short period of time (Table 1). We found that cultures produced from mussels taken outside of the predicted October to February spawning season (Tyler et al. 2007) did not develop as far or as regularly as those from mussels taken within the spawning season. Spawning of "B." childressi mussels could be consistently induced via serotonin injection by placing multiple individuals of both sexes together in one container after injection; however, using mussels that were collected in November 2003, we successfully produced a small culture that developed to the hatched blastulae stage by inducing mussels individually and obtaining sperm and eggs separately. This suggests that while the presence of gametes of conspecifics may help induce spawning in " $B$." childressi, it may not be necessary if the adults are collected while they are ripe enough to spawn and are maintained in the laboratory for a minimal time period.

Tyler et al. (2007) note that the spawning period is 3-4 months in duration, suggesting that individuals could regenerate and spawn repeatedly as seen in Mytilus edulis (Myint and Tyler, 1982). Our laboratory studies lend credence to this suggestion; we were able to induce spawning in the same mussels repeatedly over several months, and could even induce spawning in some mussels that had been maintained in the laboratory for up to one year (Table 1).

\section{Development}

Early embryonic cleavage patterns in "B." childressi are characteristic of molluscs (Figs. 1,2). As is typical for embryos developing in the cold waters of the deep-sea (Mullineaux and France, 1995; O'Connor et al., 2007), development of " $B$." childressi is slow, taking $40 \mathrm{~h}$ to reach the hatched blastula stage and about one week to begin developing shells at $7-8^{\circ} \mathrm{C}$ (Table 1$)$. We cultured larvae of "B." childressi to D-shell veligers only when the parent mussels were collected during the peak of their spawning season (Table 1) and the temperature was raised from 7-8 


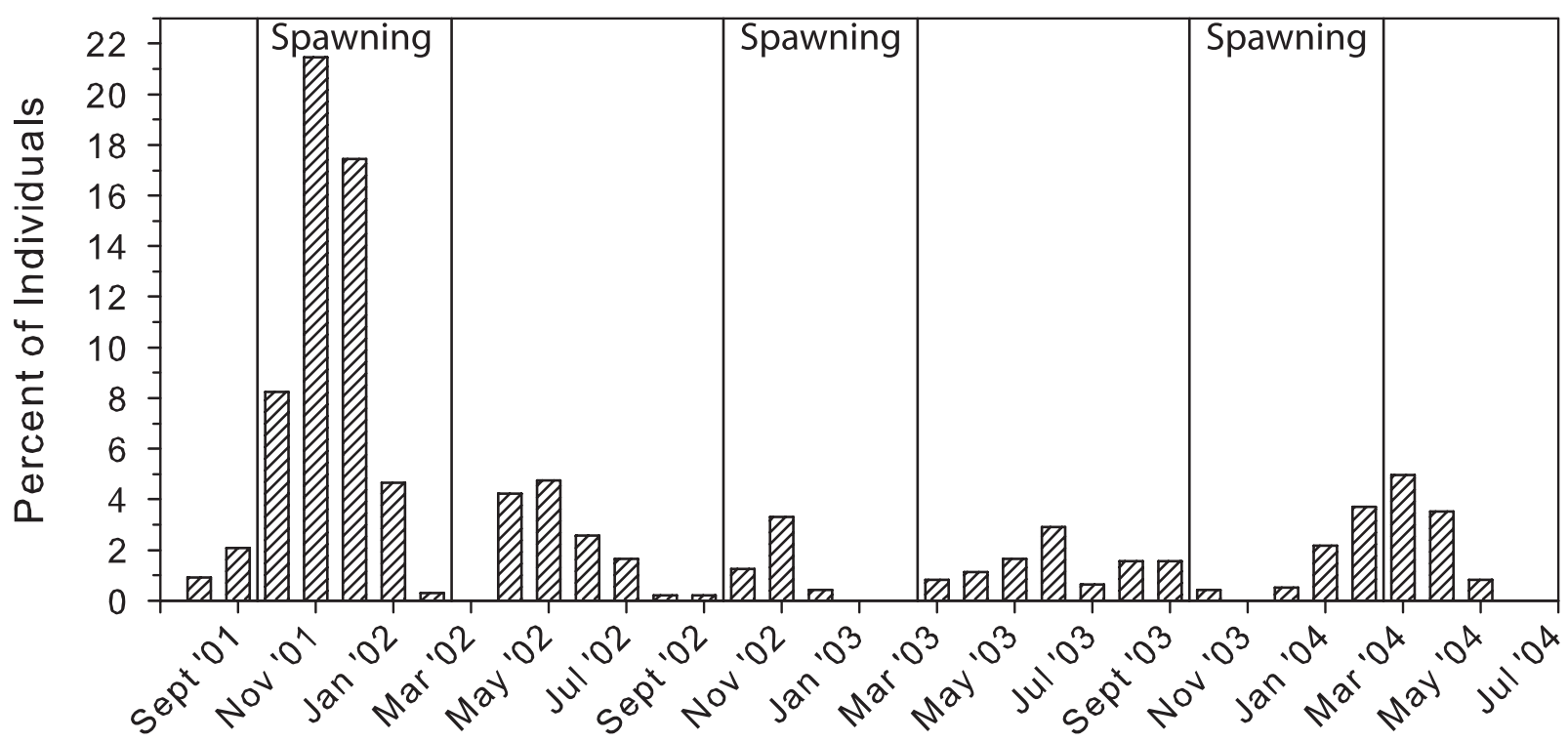

\section{Settlement month}

Figure 4. Percent of settlement $(n=969)$ by month for "Bathymodiolus" childressi at the Brine Pool cold seep over a 34-month period. Settlement dates were back-calculated from the lengths of recruits (Fig. 3), using

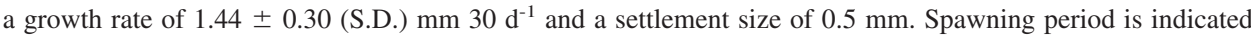
between vertical lines.

${ }^{\circ} \mathrm{C}$ to $12-14{ }^{\circ} \mathrm{C}$ immediately following hatching. D-shell veligers developed at day 8 (approx. $192 \mathrm{~h}$ ) and were maintained through day 10 (max. shell length $=103.56$ $\mu \mathrm{m})$. This growth rate is about half that of shallow-water mytilids. The shallow-water mussel Mytilus edulis develops to the D-shell veliger stage by $42 \mathrm{~h}$ at $9{ }^{\circ} \mathrm{C}$ (Strathmann, 1987), and Sprung (1984) estimates that larvae of M. edulis form a complete $\mathrm{D}$-shell at $104 \mathrm{~h}$ from fertilization at $6{ }^{\circ} \mathrm{C}$ under high food conditions $\left(40\right.$ cells ml ${ }^{-1}$ ). We were unable to rear larvae beyond the straight-hinge stage.

Because larval culturing techniques had not been developed for deep-sea hydrothermal-vent or cold-seep molluscs until now, developmental mode has been inferred in bathy-

\section{Table 3}

Estimates of planktonic larval duration of "Bathymodiolous" childressi based on major settlement peaks (from Fig. 4) and spawning seasons from October through February (Tyler et al., 2007)

\begin{tabular}{|c|c|c|}
\hline Settlement peak & Previous spawning period & $\begin{array}{l}\text { Approximate } \\
\text { larval duration }\end{array}$ \\
\hline November 2001 & October 2000-February 2001 & 9 to 13 months \\
\hline May 2002 & October 2001-February 2002 & 2 to 8 months \\
\hline November 2002 & October 2001-February 2002 & 9 to 13 month \\
\hline June 2003 & October 2002-February 2003 & 3 to 8 months \\
\hline March 2004 & October 2003-February 2004 & up to 5 months \\
\hline
\end{tabular}

modiolin mussels by examining characteristics such as egg size and the relative size of the larval shell regions (prodissoconch I and II in bivalves). Traditionally, larvae from species with small eggs are inferred to be planktotrophic and to require an extended period in the plankton, and those from species with large eggs are inferred to be lecithotrophic and settle out of the plankton relatively quickly (Thorson, 1950; Wray and Raff, 1991). The relative sizes of the prodissioconch I and II are related to oocyte size. A relatively large prodissonconch I indicates lecithotrophy since it is produced from energy reserves in the egg, while a relatively large prodissoconch II indicates planktotrophy since it is produced during feeding (Ockelmann, 1965; Lutz et al. 1980).

The egg size of "B." childressi falls within the range of those known for other bathymodiolin mussels and is indicative of planktotrophy. Mean egg diameter for "B." childressi is $69.15 \pm 2.36 \mu \mathrm{m}( \pm$ S.D.; $n=50)$. The egg diameters of the hydrothermal-vent mussels Bathymodiolus azoricus (Menez Gwen) range from 70 to $80 \mu \mathrm{m}$ (Colaço et al., 2006), Bathymodiolus puteoserpentis (Snake Pit) range from 50 to $60 \mu \mathrm{m}$ (Hessler et al., 1988), Bathymodiolus elongates (Fiji) range from 50 to $60 \mu \mathrm{m}$ (LePennec and Beninger, 1997), and Bathymodiolus thermophilus is known to have a small (about $50 \mu \mathrm{m}$ ) egg size (Berg, 1985). Egg sizes of all of the bathymodiolin mussels also fall within the 

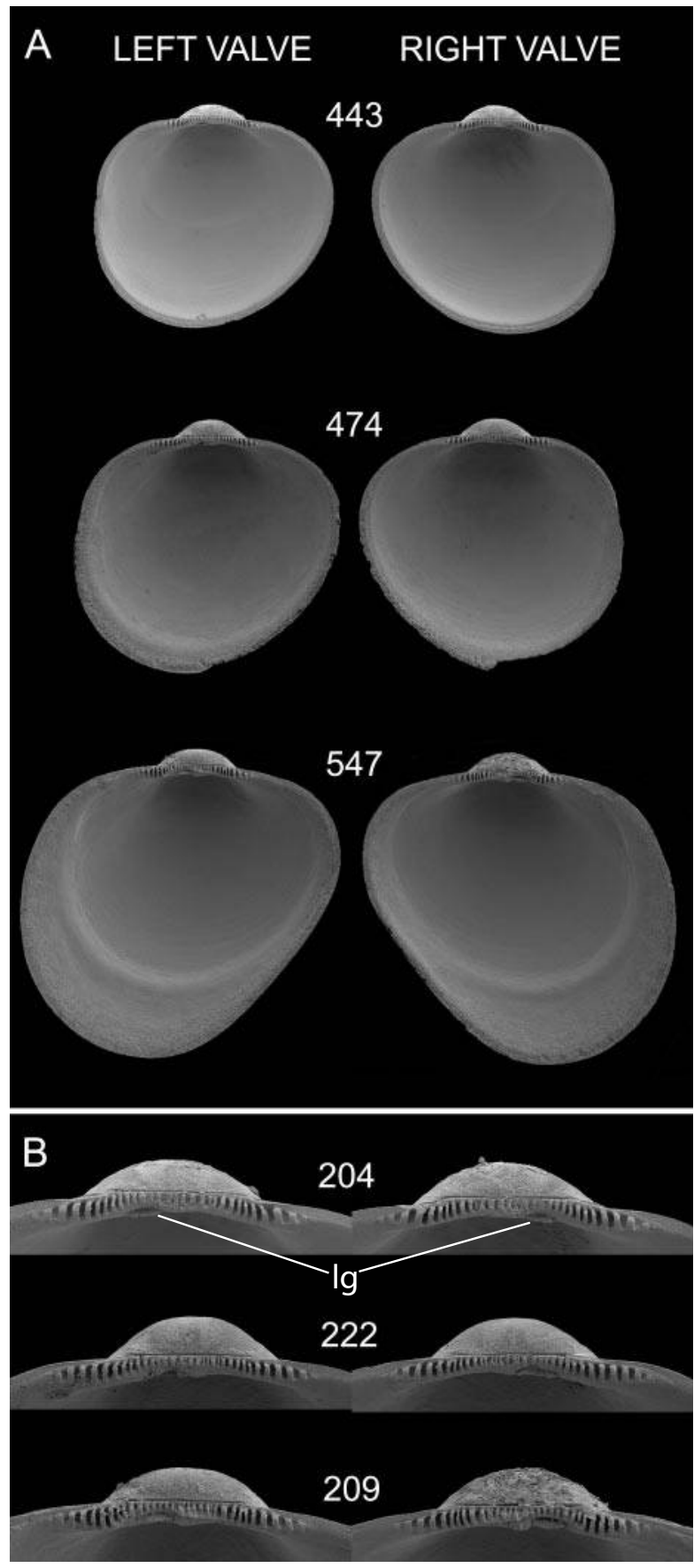

Figure 5. Larval and post-larval shells of "Bathymodiolus" childressi collected in situ in larval tube traps and on settlement plates. (A) A larval and two post-larval shells with the PII lengths $(\mu \mathrm{m})$ shown, and the corresponding photographs in (B) and the provinculum of each shell, with their lengths $(\mu \mathrm{m})$ listed. lg marks the ligament.

size range $(60$ to $90 \mu \mathrm{m})$ reported for their shallow-water relative Mytilus edulis, which has planktotrophic larvae (Lutz and Kennish, 1992).

Likewise, the relatively small prodissoconch I and large prodissoconch II of larvae of "B." childressi are indicative

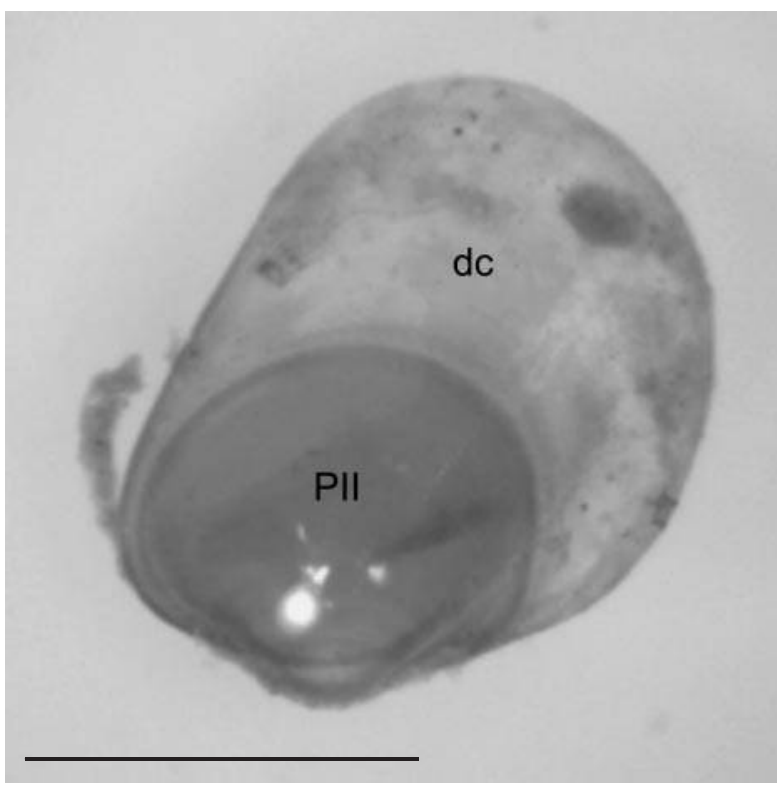

Figure 6. Post-larva of "Bathymodiolus" childressi collected in situ at the Brine Pool cold seep. Note the easy distinction of the reddish (darker gray in figure) prodissoconch II (PII) from the yellowish (lighter gray) dissoconch (dc). Scale bar $=500 \mu \mathrm{m}$.

of planktotrophy, as previously noted by Gustafson et al. (1998). In “B." childressi, the prodissoconch I length ranges from 111.45 to $115.69 \mu \mathrm{m}( \pm$ S.D. $=113.35 \pm$ 2.02) (Table 4). Similarly, five other bathymodiolin mussels from hydrothermal vents and cold seeps have prodissoconch

Table 4

Larval and post-larval shell dimensions for "Bathymodiolus" childressi

\begin{tabular}{|c|c|c|c|c|c|c|}
\hline \multirow[b]{2}{*}{ Shell type } & \multicolumn{2}{|c|}{$\mathrm{PI}^{1}$} & \multicolumn{2}{|c|}{$\begin{array}{c}\text { PII / } \\
\text { Dissoconch }{ }^{1}\end{array}$} & \multicolumn{2}{|c|}{ Provinculum } \\
\hline & Hinge $^{2}$ & Length & Length & Height & Length & \# Teeth \\
\hline D-shell ${ }^{3}$ & 71.98 & 103.56 & $\mathrm{n} / \mathrm{a}$ & $\mathrm{n} / \mathrm{a}$ & unknown & unknown \\
\hline \multirow{5}{*}{ Larval } & 91.19 & - & 453.6 & 428.08 & 221.21 & 31 \\
\hline & 89.58 & 115.69 & 443.23 & 416.45 & 204.23 & 31 \\
\hline & 90.46 & 114.35 & 434.86 & 408.54 & 202.55 & 31 \\
\hline & 89.66 & 111.45 & 448.39 & 408.96 & 222.78 & 31 \\
\hline & 86.14 & 111.9 & 432.71 & 416.10 & 199.96 & 31 \\
\hline Mean & 89.41 & 113.35 & 442.56 & 415.63 & 210.15 & 31 \\
\hline S.D. & 1.94 & 2.02 & 8.84 & 7.92 & 10.94 & 0 \\
\hline \multirow[t]{3}{*}{ Post-larval } & 92.37 & 115.81 & 474.24 & 462.56 & 222.17 & 31 \\
\hline & 91.87 & 118.73 & 546.82 & 454.17 & 209.04 & 31 \\
\hline & 92.09 & 117.42 & 547.82 & 460.76 & 212.87 & 31 \\
\hline Mean & 92.11 & 117.32 & na & na & 214.69 & 31 \\
\hline S.D. & 0.25 & 1.46 & na & na & 6.75 & 0 \\
\hline
\end{tabular}

${ }^{1} \mathrm{PI}$ and PII are the prodissoconchs I and II and are measured for D-shells and larval shells. PI and dissoconch are measured for post-larval shells.

${ }^{2}$ Hinge is the length of the hinge line.

${ }^{3} \mathrm{D}$-shell is an individual cultured in the laboratory. 
I larval shells that range from 95 to $137 \mu \mathrm{m}$ (Table 5). Prodissoconch I larval shells in shallow-water mytilids range down to $85 \mu \mathrm{m}$, as reported for Brachidontes exustus by Fuller and Lutz (1989), and up to $120 \mu \mathrm{m}$ as reported for Mytilus edulis by Sprung (1984) (Table 5). The maximum lengths of the prodissoconch II shells in bathymodiolin mussels, up to $600 \mu \mathrm{m}$ for Bathymodiolus azoricus (Salerno et al., 2005), are considerably longer than in shallow-water mytilids, which reportedly range up to only $252 \mu \mathrm{m}$ for veligers of M. edulis (Sprung, 1984) (Table 5). Considering that developmental rates are slower for "B." childressi than for M. edulis, development of bathymodiolin larvae to nearly twice the larval shell size of $M$. edulis would require a lengthy feeding time, and consequently, more time dispersing in the plankton.

Although egg size and larval shells indicate that "B." childressi has a planktotrophic larva, we were unable to confirm this with clear evidence of feeding. We usually fed Isochrysis galbana to our cultures after blastulae hatched, but we could not see autofluoresence of the algae in the gut, and cultures developed to similar stages even when they were not fed. As a matter of fact, the cultures that developed to D-shell veligers were never fed. There are a number of possible reasons we were unable to confirm feeding in the larvae of "B." childressi. First, we began offering food when larvae hatched and began swimming as ciliated blastulae. Mytilus edulis larvae develop through the blastula and trochophore stages before fully forming a mouth and gut just hours before beginning to develop their larval shells (Field, 1922). Therefore, it is possible that our cultures were simply not ready to feed. We were able to raise larvae to the shelled stages only twice (Table 1). Earlier stages were

Table 5

Larval shell characteristics of hydrocarbon-seep, hydrothermal-vent, and shallow-water mytilid mussels; PI and PII are the prodissoconchs I and II

\begin{tabular}{|c|c|c|c|c|c|c|}
\hline Habitat & Species & PI length $(\mu \mathrm{m})^{1}$ & $\begin{array}{l}\text { PII length } \\
(\mu \mathrm{m})\end{array}$ & $\begin{array}{l}\text { Provinculum } \\
\text { length }\end{array}$ & \# Teeth & Reference \\
\hline \multirow[t]{5}{*}{$\begin{array}{l}\text { Hydrocarbon } \\
\text { seep }\end{array}$} & $\begin{array}{l}\text { "Bathymodiolus" } \\
\text { childressi }\end{array}$ & $\begin{array}{c}111.45-115.69 \\
(113.35 \pm 2.02)\end{array}$ & $>453.6$ & $>222.78$ & $29-31$ & This study \\
\hline & & $100-110$ & $385-404$ & - & - & $\begin{array}{l}\text { Gustafson and Lutz, } 1994 \text { (their } \\
\text { Fig. 4.1, 4.2); Gustafson et } \\
\text { al., } 1998\end{array}$ \\
\hline & $\begin{array}{l}\text { Bathymodiolus } \\
\text { heckerae }\end{array}$ & 137 & 468 & - & - & $\begin{array}{l}\text { Turner and Lutz, } 1984 \text { (their } \\
\text { "Seep Mytilid Va"); } \\
\text { Gustafson and Lutz, } 1994\end{array}$ \\
\hline & & - & $100-600$ & - & - & Salerno et al., 2005 \\
\hline & Тати fisheri & - & 460 & - & - & $\begin{array}{l}\text { Gustafson and Lutz, } 1994 \text { (their } \\
\text { Fig. 4.3); Gustafson et al., } \\
\text { 1998 }\end{array}$ \\
\hline \multirow[t]{4}{*}{$\begin{array}{l}\text { Hydrothermal } \\
\text { vent }\end{array}$} & $\begin{array}{l}\text { Bathymodiolus } \\
\text { thermophilus }\end{array}$ & $95-110$ & $>400$ & - & - & $\begin{array}{l}\text { Lutz et al., 1980; Turner and } \\
\text { Lutz, 1984; Gustafson and } \\
\text { Lutz, } 1994\end{array}$ \\
\hline & & 108 & 470 & - & - & Berg, 1985 \\
\hline & Bathymodiolus azoricus & - & $100-600$ & - & - & Salerno et al., 2005 \\
\hline & & - & 400 & - & - & $\begin{array}{l}\text { Gustafson and Lutz, } 1994 \text { (their } \\
\text { "Vent Mytilid III") }\end{array}$ \\
\hline \multirow[t]{16}{*}{ Shallow water } & Mytilus edulis & $95-110(104.1 \pm 4.2)$ & - & $70-147$ & $19-32$ & Fuller and Lutz, 1989 \\
\hline & & 94 & - & - & - & Loosanoff et al., 1966 \\
\hline & & 95 & - & - & - & De Schweinitz and Lutz, 1976 \\
\hline & & $120 \pm 4.0$ & $120-252$ & - & - & Sprung, 1984 \\
\hline & & - & - & $71-133$ & $19-32$ & Lutz and Hidu, 1979 \\
\hline & Modiolus modiolus & $100-125$ & - & $95-165$ & $20-29$ & Fuller and Lutz, 1989 \\
\hline & & 105 & - & - & - & Lutz and Hidu, 1979 \\
\hline & Brachidontes exustus & $85-98(90.2 \pm 3.5)$ & - & $67-94$ & $16-26$ & Fuller and Lutz, 1989 \\
\hline & Brachidontes recurvus & $90-165$ & $135-220$ & - & - & Chanley, 1970 \\
\hline & Ischadium recurvum & $95-110(101.2 \pm 4.6)$ & - & $70-93$ & $17-25$ & Fuller and Lutz, 1989 \\
\hline & & 90 & - & $84-98$ & - & Chanley, 1970 \\
\hline & Geukensia demissa & $97-107(104.9 \pm 3.0)$ & - & $69-91$ & $16-22$ & Fuller and Lutz, 1989 \\
\hline & & 105 & - & - & - & Loosanoff et al., 1966 \\
\hline & & 105 & - & $80-90$ & - & Chanley, 1970 \\
\hline & Amygdalum papyrium & $85-98(92.5 \pm 3.4)$ & - & $64-84$ & $14-21$ & Fuller and Lutz, 1989 \\
\hline & & - & - & $50-70$ & - & Chanley, 1970 \\
\hline
\end{tabular}

\footnotetext{
${ }^{1}$ Values in parentheses are the mean $\pm \mathrm{SD}$.
} 
dense and opaque and we had no success with clearing techniques, making identification of a mouth and gut difficult.

Nevertheless, veligers developed to the D-shell stage without being fed algae. Survival and development in the absence of feeding is known in other bivalve larvae (e.g., Moran and Manahan, 2004). In addition, other nutritional sources are known in bivalve larvae. Dissolved organic matter (DOM) has been suggested as an energy source for bivalve larvae (Manahan, 1990), including uptake of amino acids (Manahan and Crisp, 1982; Manahan, 1983, 1989) and dissolved organic carbon (Barnard et al., 2006). Bivalve larvae, including some mytilids, are also capable of ingesting and assimilating some bacteria and heterotrophic protists (Martin and Mengus, 1977; Baldwin and Newell, 1991; Gallager et al., 1994). All of these-DOM, protists, and bacteria - are potential food sources for developing larvae of "B." childressi mussels.

Finally, unlike the shallow-water bivalves used in most studies to determine potential larval food sources, adult "B." childressi mussels use methane fixed by methanotrophic endosymbionts as their primary carbon source. Whether endosymbionts contribute energy to larvae is unclear, because the stage at which "B." childressi mussels are infected with their symbionts is unknown. Indirect evidence suggests that the hydrothermal vent mussels Bathymodiolus puteoserpentis and Bathymodiolus azoricus acquire their symbionts from the environment rather than transferring them via the ovum (Won et al., 2003). The presence of bacterial symbionts in the gill tissue of postlarvae (shell length $0.6-1.2 \mathrm{~mm}$ ) and juveniles of the vent mussel B. azoricus and the seep mussel Bathymodiolus heckerae is inferred from transmission electron microscopy (Salerno et al., 2005), but still it is unknown at what stage these mussels are actually infected. Nevertheless, Salerno et al. (2005) found no convincing evidence (by isotopic analysis of post-larvae) that the larval diet of B. azoricus or $B$. heckerae consisted of photosynthetically derived organic material.

\section{Planktonic larval duration}

In the Gulf of Mexico, there is no evidence for genetic differentiation between " $B$." childressi populations at the shallowest and deepest seep sites, nor is there a relationship between genetic and geographic distance, suggesting widespread larval dispersal of this species (Carney et al., 2006). Here we have developed culturing techniques for the first time for any deep-sea bivalve, with the expectation that information on the rate of development and length of larval period might explain the wide geographic range of " $B$." childressi.

Cultures of "B." childressi raised to the D-shell veliger stage show a definitive larval life of at least 8 days, although we kept trochophore larvae in the laboratory for more than 12 days without shell development or metamorphosis. However, it is clear from the capture of much larger late-stage larvae from the plankton that our laboratory cultures do not give a good estimate of total larval duration (Arellano, 2008). We estimated larval life spans indirectly by examining the size distribution of new recruits and comparing estimated settlement dates to the known spawning period. We calculated settlement peaks in November 2001, May 2002, November 2002, June 2003, and March 2004 (Table 3 ) and then compared those settlement dates to the most recent spawning period. The two spring peaks (May 2002 and June 2003) indicate planktonic durations of up to 8 months (Table 3). Two of the settlement peaks occurred in November (2001 and 2002), which is during the spawning season. Because larval development rates are very slow, it is extremely unlikely that these settlers came from the concurrent spawning season; if they did, their entire larval growth to $\approx 500 \mu \mathrm{m}$ would have to have taken place in less than one month. Even larvae of Mytilus edulis developing at $6{ }^{\circ} \mathrm{C}$ with much higher food concentrations than found in the deep sea would not reach the $\approx 500-\mu \mathrm{m}$ settlement size until after about 4 months of development (see fig. 2 in Sprung, 1984). We reason, therefore, that November settlers must have been drifting for at least 9 months (if they came from the end of the previous spawning season) and perhaps as long as 13 months (if from the beginning of the previous spawning season). Similarly, we estimate that settlers in March 2004 must have come either from the beginning of the October 2003-February 2004 spawning season (a larval duration of about 5 months) or from individuals spawned the previous year, in which case they might have been swimming for as little as 13 months or as long as 17 months.

Another mollusc from the cold seeps in the Gulf of Mexico has a lengthy developmental period. The snail Bathynerita naticoidea develops within egg capsules for about 4 months before it hatches as a planktotrophic larva (Van Gaest, 2006). The veliger has been maintained in the laboratory for more than 90 days after hatching (A. Van Gaest and C. M. Young, unpubl. data), and it has been captured in the plankton nearly one year after the previous hatching period (Van Gaest, 2006). Long delay of metamorphosis is not uncommon in molluscs. Indeed, veligers of the cymatiid snail Fusitriton oregonensis have been maintained in the laboratory for up to 4.5 years before metamorphosis (Strathman and Strathman, 2007)! Embryos of some hydrothermal-vent polychaetes arrest development in cold water until warmer temperatures are encountered (Pradillon et al., 2001), and metamorphosis in Mytilus edulis can be delayed if an appropriate settlement cue is not available (Bayne, 1965). Thus, a planktonic larval duration of more than one year for " $B$." childressi is entirely within reason.

The lengthy duration of larval development in the plankton suggests that the larvae of "Bathymodiolus" childressi 
may be teloplanic (long-distance dispersing). Scheltema (1966, 1971a, b, 1988) has demonstrated transatlantic dispersal of teloplanic larvae in several families of gastropods and at least two families of bivalves (Scheltema, 1971c; Scheltema and Williams, 1983). Teloplanic dispersal in "B." childressi would provide a biological explanation for the widespread dispersal of larvae of this species throughout the Gulf of Mexico and may have contributed to the transAtlantic distribution of closely related bathymodiolin congeners (Olu-Le Roy et al., 2007).

\section{Acknowledgments}

This work was supported by NSF grant OCE-0118733 to CMY. SMA was supported by an NSF graduate research fellowship and a Ford Foundation pre-doctoral fellowship. C. R. Fisher and R. S. Carney generously donated some ship and submersible time, and C. R. Fisher provided some live samples of "Bathymodiolus" childressi. K. Eckelbarger provided advice on SEM fixation procedures for larvae. S. Brooke, A. Van Gaest, T. Smart, M. Wolf, and M. Holmes helped maintain mussels in the laboratory and gave advice when needed. Culturing efforts were helped along with equipment and space from R. Emlet. We also thank M. F. Strathmann for writing an incredibly useful book on larval culturing (Strathmann, 1987).

\section{Literature Cited}

Arellano, S. M. 2008. Embryology, larval ecology, and recruitment of "Bathymodiolus" childressi, a cold-seep mussel from the Gulf of Mexico. Ph.D. dissertation, University of Oregon, Eugene.

Baldwin, B. S., and R. I. E. Newell. 1991. Omnivorous feeding by planktotrophic larvae of the eastern oyster Crassostrea virginica. Mar. Ecol. Prog. Ser. 78: 285-301.

Barnard, C., C. Martineau, J.-J. Frenette, J. J. Dodson, and W. F. Vincent. 2006. Trophic position of zebra mussel veligers and their use of dissolved organic carbon. Limnol. Oceanogr. 51: 1473-1484.

Bayne, B. L. 1965. Growth and the delay of metamorphosis of the larvae of Mytilus edulis L. Ophelia 2: 1-47.

Berg, C. J., Jr. 1985. Reproductive strategies of mollusks from abyssal hydrothermal vent communities. Biol. Soc. Wash. Bull. 6: 185-197.

Bergquist, D. C., C. Fleckstein, E. B. Szalai, J. Knisel, and C. R. Fisher. 2004. Environment drives physiological variability in the cold seep mussel Bathymodiolus childressi. Limnol. Oceanogr. 49: 706-715.

Carney, S. L., M. I. Formica, H. Divatia, K. Nelson, C. R. Fisher, and S. W. Schaeffer. 2006. Population structure of the mussel "Bathymodiolus" childressi from Gulf of Mexico hydrocarbon seeps. DeepSea Res. Pt. I 53: 1061-1072.

Chanley, P. 1970. Larval development of the hooked mussel, Brachiodontes recurves Rafinesque (Bivalvia: Mytilidae) including a literature review of larval characteristics of the Mytilidae. Proc. Natl. Shellfish. Assoc. 60: 86-94.

Clarke, A. 1983. Life in cold water: the physiological ecology of polar marine ectotherms. Oceanogr. Mar. Biol. Annu. Rev. 21: 341-453.

Colaço, A., I. Martins, M. Laranjo, L. Pires, C. Leal, C. Prieto, V. Costa, H. Lopes, D. Rosa, P. R. Dando, and R. Serrão-Santos. 2006. Annual spawning of the hydrothermal vent mussel, Bathymodiolus azoricus, under controlled aquarium, conditions at atmospheric pressure. J. Exp. Mar. Biol. Ecol. 333: 166-171.
Comtet, T., and D. Desbruyères. 1998. Population structure and recruitment in mytilid bivalves from the Lucky Strike and Menez Gwen hydrothermal vent fields $\left(37^{\circ} 17^{\prime} \mathrm{N}\right.$ and $37^{\circ} 50^{\prime} \mathrm{N}$ on the Mid-Atlantic Ridge). Mar. Ecol. Prog. Ser. 163: 165-177.

Comtet, T., M. LePennec, and D. Desbruyères. 1999. Evidence of a sexual pause in Bathymodiolus azoricus (Bivalvia: Mytilidae) from hydrothermal vents of the Mid-Atlantic Ridge. J. Mar. Biol. Assoc. UK 79: $1149-1150$.

Corliss, J. B., and R. D. Ballard. 1977. Oases of life in the cold abyss Natl. Geogr. Mag. 152: 441-453.

Corliss, J. B., J. Dymond, L. I. Gordon, J. M. Edmond, R. P. von Herzen, R. D. Ballard, K. Green, D. Williams, A. Bainbridge, K. Crane, and T. H. van Andel. 1979. Submarine thermal springs on the Galápagos Rift. Science 203: 1073-1083.

De Schweinitz, E. H., and R. A. Lutz. 1976. Larval development of the northern horse mussel, Modiolus modjolus (L.), including a comparison with the larvae of Mytilus edulis L. as an aid in planktonic identification. Biol. Bull. 150: 348-360.

Eckelbarger, K. J., C. M. Young, E. Ramirez Llodra, S. Brooke, and P. Tyler. 2001. Gametogenesis, spawning behavior, and early development in the "iceworm" Hesiocaeca methanicola (Polychaeta: Hesionidae) from methane hydrates in the Gulf of Mexico. Mar. Biol. 138: 761-775.

Field, I. A. 1922. Biology and economic value of the sea mussels Mytilus edulis. US Fish Wildl. Serv. Fish. Bull. 38: 127-160.

Fuller, S. C., and R. A. Lutz. 1989. Shell morphology of larval and post-larval mytilids from the North-Western Atlantic. J. Mar. Biol. Assoc. UK 69: 181-218.

Fuller, S. C., R. A. Lutz, and A. Pooley. 1989. Procedures for accurate documentation of shapes and dimensions of larval bivalve shells with scanning electron microscopy. Trans. Am. Microsc. Soc. 108: 58-63.

Gallager, S. M., J. B. Waterbury, and D. K. Stoecker. 1994. Efficient grazing and utilization of the marine cyanobacterium Synechococcus sp. by larvae of the bivalve Mercenaria mercenaria. Mar. Biol. 119: 251-259.

Gosling, E. M. 1992. Systematics and geographic distribution of Mytilus. Pp. 1-20 in The Mussel Mytilus: Ecology, Physiology, Genetics and Culture, E. M. Gosling, ed. Elsevier, Amsterdam.

Gustafson, R. G., and R. A. Lutz. 1994. Molluscan life history traits at deep-sea hydrothermal vents and cold methane/sulfide seeps. Pp. 76-97 in Reproduction, Larval Biology, and Recruitment of the DeepSea Benthos, C. M. Young and K. J. Eckelbarger, eds. Columbia University Press, New York.

Gustafson, R. G., R. D. Turner, R. A. Lutz, and R. C. Vrijenhoek. 1998. A new genus and five species of mussels (Bivalvia, Mytilidae) from deep-sea sulfide/hydrocarbon seeps in the Gulf of Mexico. Malacologia 40: $63-112$

Hecker, B. 1985. Fauna from a cold sulfur-seep in the Gulf of Mexico: comparison with hydrothermal vent communities and evolutionary implications. Pp. 465-473 in The Hydrothermal Vents of the Eastern Pacific: an Overview, M. L. Jones, ed. Bull. Biol. Soc. Wash. 6.

Hessler, R. R., W. M. Smithy, M. A. Boudrias, C. H. Keller, R. A. Lutz, and J. J. Childress. 1988. Temporal change in megafauna at the Rose Garden hydrothermal vent (Galapagos Rift; eastern tropical Pacifc). Deep-Sea Res. 35: 1677-1709.

Jones, W. J., Y.-J. Won, P. A. Y. Maas, P. J. Smith, R. A. Lutz, and R. C. Vrijenhoek. 2006. Evolution of habitat use by deep-sea mussels. Mar. Biol. 148: 841-851.

Le Pennec, M. 1980. The larval and post-larval hinge of some families of bivalve molluscs. J. Mar. Biol. Assoc. UK 60: 601-617.

Le Pennec, M., and P. G. Beninger. 1997. Aspects of the reproductive strategy of bivalves from reducing-ecosystem. Cah. Biol. Mar. 38: 132-133.

Le Pennec, M., and P. G. Beninger. 2000. Reproductive characteristics 
and strategies of reducing-system bivalves. Comp. Biochem. Phvsiol. A Mol. Integr. Phvsiol. 126: 1-16.

Lonsdale, P. 1977. Clustering of suspension-feeding macrobenthos near abyssal hydrothermal vents at oceanic spreading centers. Deep-Sea Res. 24: 857-863.

Loosanoff, V. L., H. C. Davis, and P. E. Chanley. 1966. Dimensions and shapes of larvae of some marine bivalve mollusks. Malacologia 4: 351-435.

Lutz, R. A., and H. Hidu. 1979. Hinge morphogenesis in the shells of larval and early post-larval mussels (Mytilus edulis L. and Modiolus modiolus (L.)). J. Mar. Biol. Assoc. UK 59: 111-121.

Lutz, R. A., and M. J. Kennish. 1992. Ecology and morphology of larval and early postlarval mussels. Pp. 53-80 in The Mussel Mytilus: Ecology, Physiology, Genetics and Culture, E. M. Gosling, ed. Elsevier, Amsterdam.

Lutz, R. A., D. Jablonski, D. C. Rhoads, and R. D. Turner. 1980. Larval dispersal of a deep-sea hydrothermal vent bivalve from the Galapagos Rift. Mar. Biol. 57: 127-133.

Lutz, R. A., D. Jablonski, and R. D. Turner. 1984. Larval dispersal at deep-sea hydrothermal vents. Science 226: 1451-1454.

MacDonald, I. R., G. S. Boland, J. S. Baker, J. M. Brook, M. C. Kennicutt II, and R. R. Bidigare. 1989. Gulf of Mexico hydrocarbon seep communities II. Spatial distribution of seep organisms and hydrocarbons at Bush Hill. Mar. Biol. 101: 235-247.

MacDonald, I. R., H. L. Guinasso, Jr., J. F. Reilly, J. M. Brooks, W. R. Callender, and S. G. Gabrielle. 1990. Gulf of Mexico hydrocarbon seep communities. VI. Patterns in community structure and habitat. Geo-Mar. Lett. 10: 244-252.

Manahan, D. T. 1983. The uptake and metabolism of dissolved amino acids by bivalve larvae. Biol. Bull. 164: 236-250.

Manahan, D. T. 1989. Amino acid fluxes to and from seawater in axenic veliger larvae of a bivalve (Crassostrea gigas). Mar. Ecol. Prog. Ser. 53: $247-255$.

Manahan, D. T. 1990. Adaptations by invertebrate larvae for nutrient acquisition from seawater. Am. Zool. 30: 147-160.

Manahan, D. T., and D. J. Crisp. 1982. The role of dissolved organic material in the nutrition of pelagic larvae: amino acid uptake by bivalve veligers. Am. Zool. 22: 635-646.

Marsh, A. G., L. S. Mullineaux, C. M. Young, and D. T. Manahan. 2001. Larval dispersal potential of the tubeworm Riftia pachyptila at deep-sea hydrothermal vents. Nature 411: 77-80.

Martin, Y. P., and B. M. Mengus. 1977. Utilisation de souches bacteriennes selectionees dans l'alimentation des larves de Mytilus galloprovincialis Lmk (Mollusque Bivalve) en elevages experimentaux [Use of selected bacterial strains for feeding larvae of Mytilus galloprovincialis Lmk in experimental rearing]. Aquaculture 10: 253-262.

Miyake, H., J. Tsukahara, J. Hashimoto, K. Uematsu, and T. Maruyama. 2006. Rearing and observation methods of vestimentiferan tubeworm and its early development at atmospheric pressure. Cah. Biol. Mar. 47: 471-475.

Moran, A. L., and D. T. Manahan. 2004. Physiological recovery from prolonged starvation in larvae of Pacific oyster Crassostrea gigas. J. Exp. Mar. Biol. Ecol. 306: 17-36.

Mortensen, T. A. 1921. Studies of the Development and Larval Forms of Echinoderms. G. E. C. Gad, Copenhagen.

Mullineaux, L. S., and S. C. France. 1995. Dispersal of deep-sea hydrothermal vent fauna. Geophys. Monogr. 91: 408-424.

Myint, M., and P. A. Tyler. 1982. Effects of temperature, nutritive and metal stressors on the reproductive biology of Mytilus edulis. Mar. Biol. 67: 209-223.

Nix, E. R., C. R. Fisher, J. Vodenichar, and K. M. Scott. 1995. Physiological ecology of a seep mussel with methanotrophic endosymbionts at three hydrocarbon seep sites in the Gulf of Mexico. Mar. Biol. 122: 605-617.
Ockelmann, K. W. 1965. Developmental types in marine bivalves and their distribution along the Atlantic coast of Europe. Pp. 25-35 in Proceedings of the First European Malacology Congress 1962, L.R. Cox and J.F. Peake, eds. Malacological Society of London, London.

O'Connor, M. I., J. F. Bruno, S. D. Gaines, B. S. Halpern, S. E. Lester, B. P. Kinlan, and J. M. Weiss. 2007. Temperature control of larval dispersal and the implications for marine ecology, evolution, and conservation. Proc. Natl. Acad. Sci. 104: 1266-1271.

Olu-Le Roy, K., R. von Cosel, S. Hourdez, S. L. Carney, and D. Jollivet. 2007. Amphi-Atlantic cold-seep Bathymodiolus species complexes across the equatorial belt. Deep-Sea Res. Part I 54: 18901911.

Paull, C. K., B. Hecker, R. Commeau, R. P. Freeman-Lynde, C. Neumann, W. P. Corso, S. Golubic, J. E. Hook, E. Sikes, and J. Curray. 1984. Biological communities at the Florida Escarpment resemble hydrothermal vent taxa. Science 226: 965-967.

Pearse, J. S. 1994. Cold-water echinoderms break "Thorson's Rule." Pp. 26-43 in Reproduction, Larval Biology and Recruitment of the Deep Sea Benthos, C. M. Young and K. J. Eckelbarger, eds. Columbia University Press, New York.

Pradillon, F., N. Le Bris, B. Shillito, C. M. Young, and F. Gaill. 2005. Influence of environmental conditions on early development of the hydrothermal vent polychaete Alvinella pompejana. J. Exp. Biol. 208: $1551-1561$.

Prouho, H. 1888. Recherches sur le Dorocidaris papillata et quelques autres échinides de la Méditerranée. Arch. Zool. Exp. Gen. 2: 213-380.

Rees, C. B. 1950. The identification and classification of lamellibranch larvae. Hull Bull. Mar. Ecol. 3: 157-172.

Salerno, J. L., S. A. Macko, S. J. Hallam, M. Bright, Y.-J. Won, Z. McKiness, and C. L. Van Dover. 2005. Characterization of symbiont populations in life-history stages of mussels from chemosynthetic environments. Biol. Bull. 208: 145-155.

Scheltema, R. S. 1966. Evidence for trans-Atlantic transport of gastropod larvae belonging to the genus Cymatium. Deep-Sea Res. 13: 83-95.

Scheltema, R. S. 1971a. Larval dispersal as a means of genetic exchange between geographically separated populations of shallow-water benthic marine gastropods. Biol. Bull. 140: 284-322.

Scheltema, R. S. 1971b. The dispersal of the larvae of shoal-water benthic invertebrate species over long distances by ocean currents. Pp 7-28 in Fourth European Marine Biology Symposium, D. J. Crisp, ed. Cambridge University Press, Cambridge.

Scheltema, R. S. 1971c. Dispersal of phytoplanktotrophic shipworm larvae (Bivalvia: Teredinidae) over long distances by ocean currents. Mar. Biol. 11: 5-11.

Scheltema, R. S. 1988. Initial evidence for the transport of teleplanic larvae of benthic invertebrates across the East Pacific barrier. Biol. Bull. 174: $145-152$.

Scheltema, R. S., and I. P. Williams. 1983. Long-distance dispersal of planktonic larvae and the biogeography and evolution of some Polynesian and western Pacific mollusks. Bull. Mar. Sci. 33: 545-565.

Smith, E. B., K. M. Scott, E. R. Nix, C. Korte, and C. R. Fisher. 2000. Growth and condition of seep mussels (Bathymodiolus childressi) at a Gulf of Mexico brine pool. Ecology 81: 2392-2403.

Sprung, M. 1984. Physiological energetics of mussel larvae (Mytilus edulis). I. Shell growth and biomass. Mar. Ecol. Prog. Ser. 17: 283 293.

Strathmann, M. F. 1987. Reproduction and Development of Marine Invertebrates of the Northern Pacific Coast: Data and Methods for the Study of Eggs, Embryos, and Larvae. University of Washington Press, Seattle.

Strathmann, M. F., and R. R. Strathmann. 2007. An extraordinarily long larval duration of 4.5 years from hatching to metamorphosis for teleplanic veligers of Fusitriton oregonensis. Biol. Bull. 213: 152-159. 
Thorson, G. L. 1950. Reproductive and larval ecology of marine bottom invertebrates. Biol. Rev. 1: 1-46.

Turner, R. D., and R. A. Lutz. 1984. Growth and distribution of mollusks at deep-sea vents and seeps. Oceanus 27: 55-62.

Turner, R. D., R. A. Lutz, and D. Jablonski. 1985. Modes of molluscan larval development at the deep-sea hydrothermal vents. Pp. 167184 in The Hydrothermal Vents of the Eastern Pacific: An Overview, M. L. Jones, ed. Bull. Biol. Soc. Wash.

Tyler, P. A., and C. M. Young. 1999. Reproduction and dispersal at vents and cold seeps. J. Mar. Biol. Assoc. UK 79: 193-208.

Tyler, P., C. M. Young, E. Dolan, S. M. Arellano, S. D. Brooke, and M. Baker. 2007. Gametogenic periodicity in the chemosynthetic coldseep mussel "Bathymodiolus" childressi. Mar. Biol. 150: 829-840.

Van Gaest, A. 2006. Ecology and early life history of Bathynerita naticodea: evidence for long-distance larval dispersal of a cold seep gastropod. M.S. thesis, University of Oregon, Eugene.

Won, Y.-J., S. J. Hallam, G. D. O'Mullans, I. L. Pan, K. R. Buck, and R. C. Vrijenhoek. 2003. Environmental acquisition of thiotrophic endosymbionts by deep-sea mussels of the genus Bathvmodiolus. Appl. Environ. Microbiol. 69: 6785-6792.

Wray, G. A., and R. A. Raff. 1991. The evolution of developmental strategy in marine invertebrates. Trends Ecol. Evol. 6: 45-50.

Young, C. M. 1994. A tale of two dogmas: the early history of deep sea reproductive biology. Pp. 1-25 in C. M. Young and K. J. Eckelbarger, eds. Reproduction, Larval Biology and Recruitment of the Deep Sea Benthos. Columbia University Press, New York.

Young, C. M. 2003. Reproduction, development and life-history traits. Pp. 381-426 in Ecosystems of the World, Vol. 28, Ecosystems of the Deep Oceans, P.A. Tyler, ed. Elsevier, Amsterdam.

Young, C. M., and J. L. Cameron. 1989. Development rate as a function of depth in the bathyal echinoid Linopneustes longispinus. Pp. 225-231 in Reproduction, Genetics and Distributions of Marine Organisms, J. S. Ryland and P. A. Tyler, eds. Olsen \& Olsen, Fredensborg, Denmark.

Young, C. M., and S. B. George. 2000. Larval development of the tropical deep-sea echinoid Aspidodiadema jacobyi: phylogenetic implications. Biol. Bull. 198: 387-395.

Young, C. M., and P. A. Tyler. 1993. Embryos of the deep-sea echinoid Echinus affinis require high pressure for development. Limnol. Oceanogr. 38: 178-181.

Young, C. M., J. L. Cameron, and K. J. Eckelbarger. 1989. Extended pre-feeding period in planktonic larvae of the bathyal echinoid Aspidodiadema jacobyi. J. Mar. Biol. Assoc. UK 69: 695-702.

Young, C. M., J. D. Gage, and P. A. Tyler. 1996a. Vertical distribution correlates with pressure tolerances of early embryos in the deep-sea asteroid Plutonaster bifrons. J. Mar. Biol. Assoc. UK 76: 749-757.

Young, C. M., E. Vázquez, A. Metaxas, and P. A. Tyler. 1996 b. Embryology of vestimentiferan tube worms from deep-sea methane/ sulphide seeps. Nature 381: 514-516.

Young, C. M., P. A. Tyler, and L. Fenaux. 1997. Potential for deep sea invasion by Mediterranean shallow water echinoids: pressure and temperature as stage-specific dispersal barriers. Mar. Ecol. Progr. Ser. 154: 197-209.

Young, C. M., M. A. Sewell, P. A. Tyler, and A. Metaxas. 1999. Biogeographic and bathymetric ranges of Atlantic deep-sea echinoderms and ascidians: the role of larval dispersal. Biodivers. Conserv. 6: $1507-1522$.

Yund, P. O., S. D. Gaines, and M. D. Bertness. 1991. Cylindrical tube traps for larval sampling. Limnol. Oceanogr. 36: 1167-1177. 